\title{
The relationship between identity and vulnerability values in carrying out interventions in protected urban areas
}

\author{
C. O. Gociman ${ }^{1}$, C. I. Moscu ${ }^{1} \&$ E. S. Georgescu ${ }^{2}$ \\ 1"Ion Mincu" University of Architecture and Urban Planning, Romania \\ ${ }^{2}$ The National Institute for Research and Development URBAN- \\ INCERC, Romania
}

\begin{abstract}
Human settlements, the result of continuous living on a territory, acquire classified heritage values over time, but mostly they keep specific ways of spatial organization building that identify a community. In this respect, the "Convention for Architectural Heritage Safeguarding" promulgated by the Council of Europe - Granada 1985 - stated "the desire to preserve a place's identity mentioning the importance of transmitting a system of cultural references to future generations". Thus, destroying spatial landmarks by earthquakes and by demolition and large scale reconstruction during the communist period in Bucharest destroys the public memory. This paper aims to identify the critical apparatus meant to base the analysis of a built area exposed to multi-hazards in a balanced relationship between the cultural and functional value as a reporting identity size, and its state vulnerability value related to security of space and environment on the other side. The concept of cultural value has been enhanced by details of scoring criteria and methods, based on the 6 scaling stages of the Monuments Law. The functional value of a built area has been set by the provisions of the Construction Code on the important classes of buildings and of course by the provisions of the Urban Plan, regarding functional zoning. Use value status has been defined in accordance with law of "Quality of Constructions" and defines the way listed requirements are met, regarding structural safety, fire safety and reliability of operation and also in terms of environmental quality assessments (lighting, thermal and sound protection). Intervention strategies on built protected area as current maintenance; conservative maintenance; conservative intervention; restoration; partial restructuring; global restructuring; demolition; new proposals
\end{abstract}


shall be the result of a holistic relationship between reporting identity and vulnerability values.

\section{Introduction}

In Bucharest, the post-seismic strategy of March 4, 1977 disaster turned from strengthening and rehabilitation into the demolition of the old affected tissue. The reconstruction of 450 ha of the city affected one third of the urban population. The drama of one's uprooting, loss of identity, of the destruction of communities left unhealed traces.

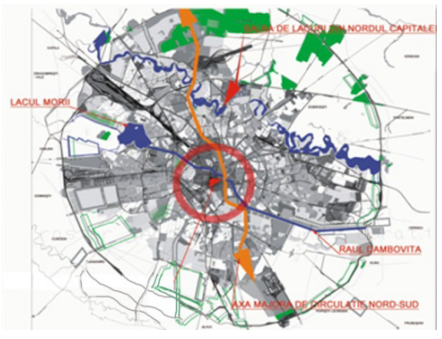

Figure 1: General urban plan of Bucharest [1].

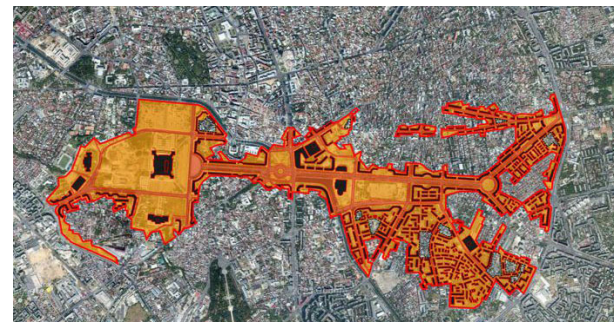

Figure 2: Building area demolished at Nicolae Ceausescu's order in the Old City Centre [2].

The fair reaction to multi-hazard as well as to the aggressive contemporary real estate developments requires a fair assessment of the built existing fund that can become the renewable resources, and particularly to the heritage that must be protected as unrenewable resource.

The research aims to identify the critical apparatus that would underlie the analysis of the built fund exposed to multi-hazard, as well as to the pressures of developers, in a balanced relation between the cultural and functional value of significance and its value of vulnerability. The objectives will be related to identifying the methodologies of establishing the urban and architectural intervention decisions that would support the territory development in terms of protecting the existing fund and the exposed heritage.

\section{Methodology}

Given the inter- and trans-disciplinary character of the project, the stages were determined by referring to the following relevant aspects: the potential of multihazard at the site, evaluation of the urban tissue, existing habitat, architectural heritage of the towns - significance and vulnerability value and the changes of paradigms, from the intervention per built object to the radical one, of urban remodelling or recovery that are to be taken into account in each subfield, in correlation with the level of development, in order to choose the approaches applicable in the territory. 


\section{International policies to reduce the risk of disasters}

During the $20^{\text {th }}$ Century, only earthquakes have caused the death of 1.5 million people worldwide, causing material losses, estimated only for the past 25 years of the century to be $\$ 75$ billion. The decade $1990-2000$ was declared by the UN the International Decade for Natural Disaster Reduction (IDNDR-UN), while in 2005, at the World Conference on Disaster Reduction, Kobe, 2005, the International Strategy for Disaster Reduction - ISDR was adopted, coordinated by the UN within IDNDR, through the Yokohama Strategy and Plan of Action.

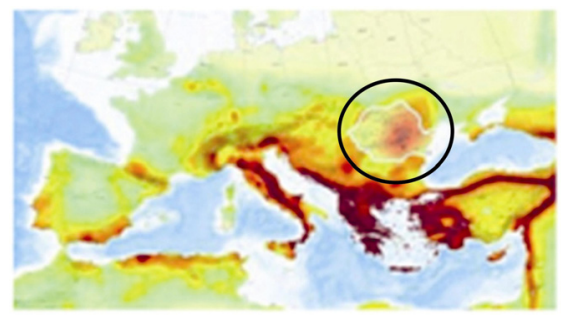

Figure 3: $\quad$ Seismic map of Europe [3].

As of 2010, the requirements of the European Union are represented by The Internal Security Strategy in Action - SEC (2010), since European Commission recommendations aim to collect the data to elaborate the maps of risks and guidelines with the minimum standards for disaster prevention.

\section{Conceptual framework}

\subsection{Limit or sustainable development theory}

The theory of "development limit" supported by the Club of Rome in XX century has triggered the alarm on consuming the development support. In 1998, the Brundtland report suggested a new theory, of "sustainable development". "The environment cannot be separated from human actions, ambitions and needs" [4]. The "environment" that anthropocentrism misperceives as materials designed to be used exclusively by humans, to serve the needs of humanity, is in the profoundest sense humanity's source and support: its ingenious, inventive life-giving matrix (Rowe [5]).

\subsection{Principle of ecosystem approach}

The ecosystem approach within the sustainable development requires an understanding of the natural environment based on its component ecosystems as well as the assimilation of other unnatural systems. The anthropised ecosystem is a slow assaulted system and is defined as the current moment of the natural ecosystem. The psychological and social values of the place are related to the individual and collective experience within the two ecosystems, the natural and 
the anthropised ones, explaining a dual man-space relationship. The two components, the living (anthropocenosis) and the non-living (the supporting space - anthropised biotope) are linked through ecological processes (Budeanu and Calinescu [6]).

\section{Ecosystem entropies}

\subsection{Geological hazard - seismicity in Vrancea area and the nature of the subsoil}

Bucharest is mainly affected by intermediate depth (from Vrancea) earthquakes. Among the major earthquakes of Vrancea, those in 1471, 1620, 1738, 1802, $1829,1838,1940,1977,1986$ and 1990 are significant. The nominal "epicentral" distance is moderate, but all these major earthquakes affect Bucharest, because the attenuation to location is relatively low. After the Vrancea March 4, 1977 earthquake (M 7.2), from the total of US\$ 2 billion loss, approx. US\$ 1.42 billion were in construction (buildings, water supply etc.), of which 1.03 billion were housing (over $50 \%$ of the total) being the most affected (World Bank Report [7]). The disaster was higher in Bucharest, where $70 \%$ of the losses were recorded. Overall, the local land conditions in the municipality, at a considerable depth, influence some characteristics of seismic motions, depending on spectral characteristics and dynamic amplification on certain frequency ranges, the liquefaction potential, etc.

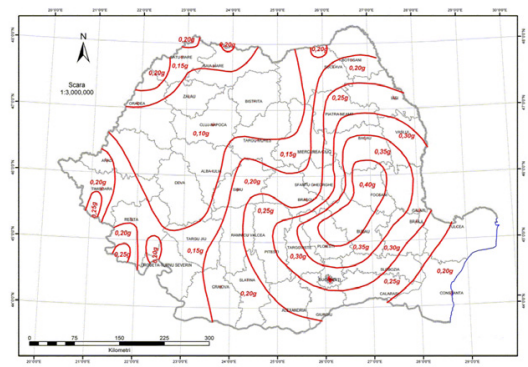

Figure 4: Romania - Seismic zonation for design of buildings; Peak Ground Acceleration for Mean Recurrence Interval of 225 years and 20\% exceedance probability in 50 years (Code P100-1/2013, MDRAP, [8]).

Other hazards:

Hydrological hazard - floods from extreme accidents in water storage lakes downstream from the city, on the route of Dambovita.

Meteorological hazard - high differences in temperatures $\left(-30^{\circ} \mathrm{C}\right.$ in winter, $+40^{\circ} \mathrm{C}$ in summer) rains, snows, frost, rains.

Anthropic hazards - may be fires in houses and other buildings; explosions on the gas networks; terrorist explosions in nearby public institutions; toxic gas 
clouds from accidents in food industries in the city (e.g. ammonia); terrorism; manifestations; strikes.

Combinated anthropic hazards - NaTech are a successive developed event like earthquake, explosion, chemical accident, etc.

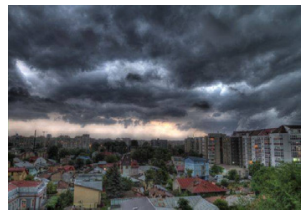

Figure 5: Storm in Bucharest [9].

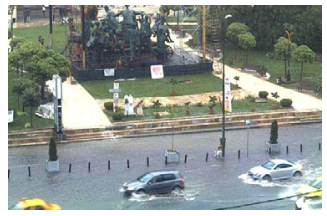

Figure 6: Flooding [9].

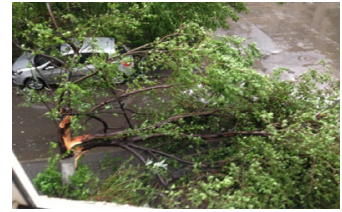

Figure 7: Collapsing trees in Bucharest [9].

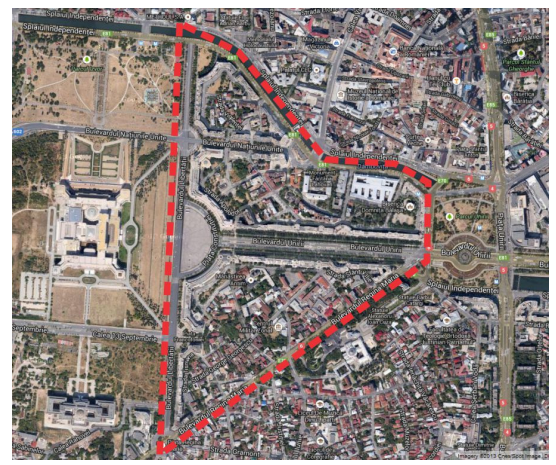

Figure 8: $\quad$ Studied area - Bucharest Civic Center [10].

\subsection{Analysis of the anthropised ecosystem}

The study area is the one destructured by the demolitions of the communist regime in the so-called Civic Centre, near Parliament. The current situation of Bucharest and of the studied area still in the post-trauma stage cannot be understood without a European political key, which implies an insight into the history of the $19^{\text {th }}$ and $20^{\text {th }}$ centuries in relation to the concept of urban reconstruction under authoritarian regimes, studied by Cavalcanti [11]. After the 1977 earthquake, instead of strengthening and rehabilitation, Ceausescu forced demolition and restructuration for a new center. Social alienation, loss of publiccommunity memory and large-scale reconstructions of the $80 \mathrm{~s}$ in Bucharest are compared to the major interventions of urban remodelling in other capitals, such as Paris (under Napoleon III), Moscow (under Stalin), Berlin (under Hitler) and Roma (under Mussolini), the major heritage of which was partially or fully affected.

In his book, "Existence, Space \& Architecture", Norberg-Schulz decodes the hierarchy of the existential space levels, relative to human and their actions [12]. 


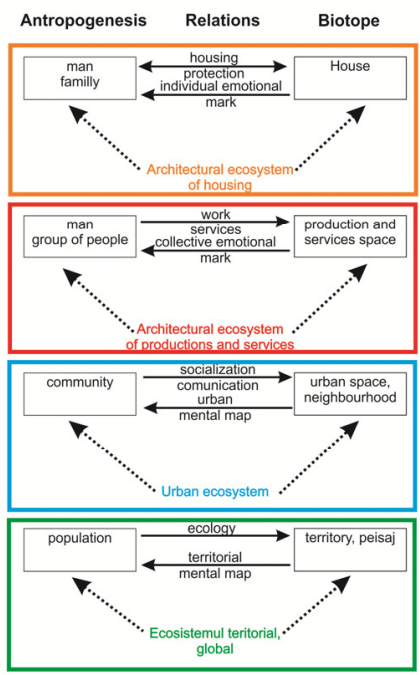

Figure 9: Anthropic ecosystem organization.

\subsubsection{Anthropogenesis}

The man is an anthropocentric unit who survive only in family. As a form of organisation, the community is a social group "with common interests, beliefs, customs, life rules' collectivity, society" (Budeanu and Calinescu [13]). In his attempt to define the community, Pitulac highlights the multitude and multiplicity of the meanings acquired by this sociological concept which, as many other concepts, is tributary to the "residual associations" and meanings attached to words (Pitulac [14]).

Tonnies compares the community in relation to the society "community means genuine, enduring life together and this is why it must be understood as a living organism in its own right, whereas society is a transient and superficial thing, like a mechanical aggregate" (Tonnies [15]).

The community is essentially a unitary whole acting by directly using the thing it has in common. The society is a sum of individual actions that express their will through a free social deed, the exchange.

\subsection{Biotope - supporting space - habitat}

The configuration of the habitat is an expression of the geo-climatic, socialpolitical and religious determinations of each community as a result of its organic development.

"The patrimonial habitat is spatially finite - by accumulation on the territory, but infinite temporally due to the selection caused by the evolution of the community expressing an energetic balance between tradition and innovation. The mobility and ability to adapt and assimilate the contemporary values describe an operating mode specific to the ecosystem - self-adjustment" (Gociman and Dinu [16]). 


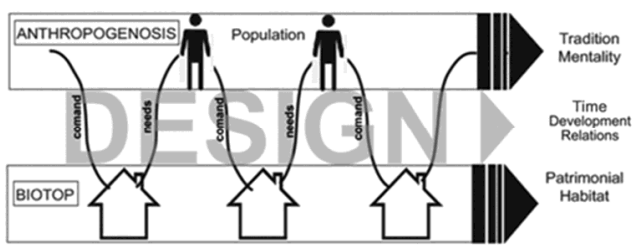

Figure 10: Evolution of the built space ecosystem.

The relationship between space and its emotional footprint causes the stability area of the "place", which if it is deconstructed by a hazard, it creates alienation and uprooting. For Heidegger, living is how people exist on Earth, the essential character of living is to spare and preserve (Heidegger [17]).

Architecture must proceed towards open definitions of the concepts upon which it has been built over time. These definitions must keep all the sediments of the historical evolution of the architectural space, which acquired refinement by their constant reformulation and meaning by creating experiences.

\subsection{Mental map}

Continuing the techniques of Lynch - "Image of the city" [18] and Gould [19], many studies have shown that most individuals carry within a "mental map" of their surrounding physical framework, and it seems to be distinct, based on the unique individual formation and individual experience.

Blessing [20] argues that, in the urban field, the city design is not found on the systemizing architects' boards, but in the mind and spirit of population, that implies a psychological understanding of our cities. Lynch and others have tried to determine the physical features that are selected and which a resident remembers in connection with their urban environment, defining three components for the analysis of each ambient image: identity, structure and meaning (Lynch [18]).

We may also show that these personal factors are related to an individual's capacity to adapt to their surrounding framework, which is particularly relevant in the case of environmental changes, which often cause stress (Wolpert [21]).

\section{International policies on heritage}

The "European Charter of the Architectural Heritage" and "Declaration of Amsterdam" [22] specify: "Heritage includes not only individual buildings of exceptional value, but also their context, all areas of towns or villages of historic or cultural interest". Thus, the patrimonial habitat is a vital landmark. In this sense, it is affirmed in the "Convention for the Protection of the Architectural Heritage" promulgated by the European Council - Granada [23]. At municipal level, but particularly at local level, it is required to assess the entire built fund as cultural resource, in order to establish the coherence, identity and not last the dimension of the emotional footprint. Romanians, especially in Bucharest, attach 
to a place for a lifetime, proving great locative stability. Destroying the spatial landmarks becomes a major risk for the psycho-social balance of inhabitants.

\section{Case study - historical analysis}

The area is part of the historical "home" of the city, with more than 40 monuments listed, with a built fund of variable ages, some dating even since the end of the $16^{\text {th }}$ century. The evolution of the area may be seen by analysing the city plans since 1852, 1895-1899, 1911 and 1977:

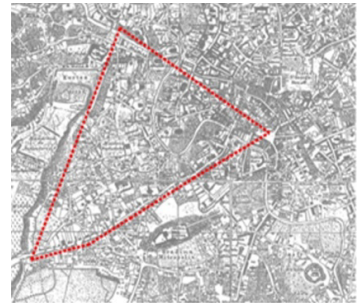

Figure 11: Borroczyn Plan Figure 12: Bucharest Plan Figure 13: Bucharest Plan 1852 [24].

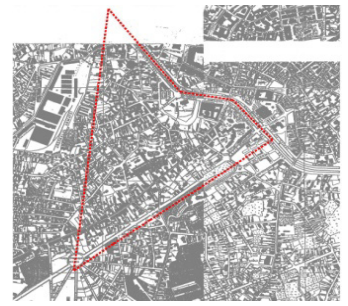

1895-1899 [24].

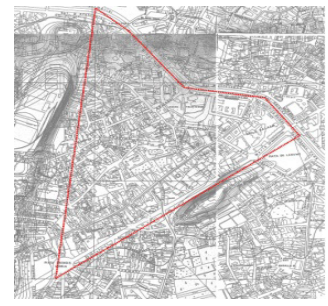

$1911[24]$

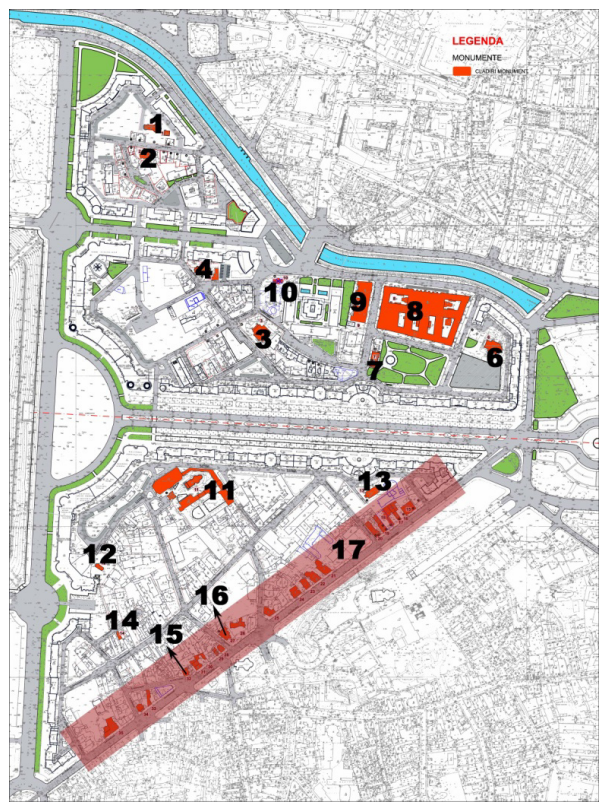

Figure 14: Historical monuments in the area of study [25]. 
The key for Figure 14 is as follows:

1. The Assembly of Mihai-Vodă Monastery of $17^{\text {th }}$ century, No.4, Strada Sapientei nr.4, moved from Dealul Mihai Vodă; The Church "Sf. Ierarh Nicolae" (St. Nicholas) - Mihai Vodă, Strada Sapienţei nr.4.

2. The "Assumption of Mary" Church - Strada Sapientei nr.5.

3. "Oprea Soare" House, Strada Apolodor nr.1, 1914, Architect Petre Antonescu.

4. Assembly of the Church "Sf. Apostoli" (The Apostles), Strada Sfinţii Apostoli nr.1; Parochial House $16^{\text {th }}-20^{\text {th }}$ centuries.

5. Foundations of the Tarnovului Monastery $16^{\text {th }}$ century.

6. The "Înălţarea Domnului" (The Exaltation) Domniţa Bălaş.

7. Residential building - Prof. Dr. Marinescu, Strada Danielopol Gheorghe nr. 3 , first half of the $20^{\text {th }}$ century.

8. Palace of Justice Splaiul Independenţei nr.1, 1927; Architect Ion Mincu Andrei Ballu.

9. High Court of Justice, Splaiul Independentei nr.5.

10. The Church "Sf. Spiridon".

11. Group of the Antim Monastery, 29, Strada mitropolit Ivireanu Antim: The Church "Toţi Sfinţii" (All Saints), 1714; Chapel, 1715; Shrines; Kitchen, 1715; Bell Tower, $19^{\text {th }}$ century.

12. Schitul Maicilor (Nuns Skete).

13. The Church "Sf. Ilie" (St. Elias - Rahova, 79, Strada Silvestru Constantin (1838).

14. House no. 12A, Strada Gladiolelor; House no. 12, Strada Gladiolelor; beginning of the $20^{\text {th }}$ century.

15. House no.15, Strada Poiana Florilor; $19^{\text {th }}$ century.

16. House no. 36, Strada Justitiei.

17. Group of homes on Maria Boulevard.

\section{Built space}

\subsection{Cultural value analysis}

In this research, the concept of cultural value has been amplified by detailing the scoring criteria and methods. Starting from the 6 stages of value from the Monuments Act, I considered an approach synchronous with them is required and I also suggested 6 evaluation stages. This concept of cultural value has been enhanced in this research theme by 13 criteria details and grading artistic, architectural, urbanistic, functional, structural, technical execution, decorative, furnishing conception, local, religious, ethnical, seniority, historical, political or memorial references. The authors believe in a synchronous approach and therefore, six evaluation stages have been recommended, from 0 to 5 . At first we proposed to analyse the intrinsic value of genuineness and secondly associated values of the relative artistic, technical, rarity, cultural identity values. The grading value obtained by the evaluation will form criteria for value classification. 
Table 1: Built fund - value classification [26].

\begin{tabular}{|c|l|l|}
\hline $\begin{array}{c}\text { Actual total } \\
\text { score }\end{array}$ & Minimum score by criteria & Classification of values \\
\hline$\geq 65 \mathrm{p}$ & $\begin{array}{l}\text { Min. 25p Authenticity } \\
\text { Min. 20p Relative artistic and technical value } \\
\text { Min. 20p Rarity value }\end{array}$ & Special cultural value \\
\hline $30-50 \mathrm{p}$ & $\begin{array}{l}\text { Min. 10p Authenticity + } \\
\text { Min. 10p Relative artistic and technical value } \\
\text { Min. 10p Rarity value }\end{array}$ & Typological cultural value \\
\hline $20-30 \mathrm{p}$ & $\begin{array}{l}\text { Min. 10p Relative artistic and technical value } \\
\text { Min. 10p Cultural identity value }\end{array}$ & Ambient cultural value \\
\hline $10-20 \mathrm{p}$ & $\begin{array}{l}\text { Min. 5p Relative artistic and technical value } \\
\text { Min. 5p Cultural identity value }\end{array}$ & Cultural identity value \\
\hline $5-10 \mathrm{p}$ & $\begin{array}{l}\text { Min. 5p Relative artistic and technical value or } \\
\text { Min. 5p Cultural identity value }\end{array}$ & Minor cultural value \\
\hline $0 \mathrm{p}$ & $0 \mathrm{p}$ & No value \\
\hline
\end{tabular}

\subsection{Functional value analysis}

The functional value of the built fund must take into account the provisions of code P100/2006 on the classes of importance of the buildings and of course, the provisions of the general urban planning (GUP) of Bucharest regarding the functional area and is evaluated through the same operation scale as $\mathrm{C}$ - central zone, $\mathrm{M}$ - mixed zone, $\mathrm{L}$ - housing zone, $\mathrm{V}$ - green spaces, $\mathrm{T}$ - transport zone, $\mathrm{G}$ - communal household, $\mathrm{S}$ - special equipment.

\subsection{Affiliation analysis}

Affiliation analysis take in consideration the react of individuals, communities in relations with built space like - affinity, familiarity, attraction, rejection or institutional pressure scoring 6 steps from 0 to 5 .

\subsection{The reporting value}

The reporting value is the average of cultural, functional and affiliation values and is a fundamental determination for community perception.

Table 2: $\quad$ Structure of reporting value.

\begin{tabular}{|l|l|l|l|l|l|l|l|}
\hline & Criterion & 0 & 1 & 2 & 3 & 4 & 5 \\
\hline 1 & Cultural value & & & & & & \\
\hline 2 & Functional value & & & & & & \\
\hline 3 & Affiliation value & & & & & & \\
\hline & Reporting value $\varepsilon(1,2,3) / 3$ & & & & & & \\
\hline
\end{tabular}




\subsection{Vulnerability analysis}

\subsubsection{Urban space}

The vulnerability of urban space can be analyzed in connection with topography of the support space, about conformation of the streets, squares or such like proportion of planimetric and volumetric characteristics, type of overall compliance organisation of access, green area and quality of equipment.

\subsubsection{The built space - vulnerability (state) analysis}

The value of the state use is defined in compliance with Romanian Law 10/1995, "Quality in Constructions" and defines how the listed requirements are met. The state of the building and its value of use is the result of how users have used it and also the result of sudden or slow hazards which it has been exposed to over time.

Table 3: Built fund and value of vulnerability.

\begin{tabular}{|c|l|c|c|c|c|c|c|}
\hline No. & Criterion & \multicolumn{6}{|c|}{ Vulnerability values } \\
\hline 1 & Safety & 0 & 1 & 2 & 3 & 4 & 5 \\
\hline 1.1 & - mechanical endurance and stability & & & & & & \\
\hline 1.2 & - safety in operation & & & & & & \\
\hline 1.3 & Safety to fires & & & & & & \\
\hline & Average value of safety & & & & & & \\
\hline 2 & Quality of the environment & & & & & & \\
\hline 2.1 & Hygiene, health, environment & & & & & & \\
\hline 2.2 & Thermal protection, energy saving & & & & & & \\
\hline 2.3 & Noise protection & & & & & & \\
\hline 2.4 & Waterproofing & & & & & & \\
\hline 2.5 & Sunlight & & & & & & \\
\hline & $\begin{array}{l}\text { Average quality value of the } \\
\text { environment }\end{array}$ & & & & & \\
\hline
\end{tabular}

We have grouped the criteria from the law into two groups - safety and quality of the environment. Every criterion may be developed into specific sub criteria.

8.5.2.1 (Structural vulnerability) safety analysis The analysis based on the score from the Code P100-3/2008 [7]. requires a lot of data which would impose special time to analyse each building. According to the evaluations the Ministry of Constructions has proposed a list of valued and exposed buildings. The elements exposed to risk are classified to estimate the vulnerability, depending on the structural type, height and construction period. Residential buildings are classified into combinations of 7 types of materials, 6 classes or periods of age and 5 classes or regimes of height. (Sandi et al. [27]).

For the systematic, multi-criteria and multi-hazard analysis of the buildings in the study area, the URBASRISKdb database was established. The URBASRISKdb database is done by means of the specialised Microsoft Access 
application, which has the advantage of directly interfacing with the ESRI ArcView application used to map the vulnerability characteristics, as well as with the Microsoft Excel software, used to store the various information in tables, which refer to the studied urban area. (Project URBASRISK) [28].

\section{Intervention decision}

From the practice of operation project of existing buildings, in accordance with the generic recommendation of project for protected area [29].

Table 4: Intervention decision.

\begin{tabular}{|c|c|c|}
\hline & Code & Intervention categories \\
\hline \multirow{2}{*}{$\frac{e^{2}}{\sum_{2}^{2}}$} & $\mathbf{A}$ & $\begin{array}{l}\text { Current maintenance: repairs, local restoration and replacements } \\
\text { installations repairs and modifications. }\end{array}$ \\
\hline & B & $\begin{array}{l}\text { Conservative maintenance: idem+local strengthening interventions or } \\
\text { replacements of some damaged structural elements. }\end{array}$ \\
\hline \multirow[t]{2}{*}{ 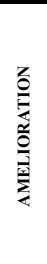 } & $\mathbf{C}$ & $\begin{array}{l}\text { Conservative works: works meant for the conservation and insurance of } \\
\text { functionality of the building, observing its typological, formal and } \\
\text { structural characteristics and ensuring a compatible function, } \\
\text { consolidation or restoration of some structural components with } \\
\text { analogous or compatible materials and techniques. }\end{array}$ \\
\hline & D & Restoration and strengthening. \\
\hline \multirow{4}{*}{ 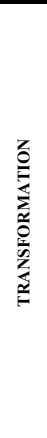 } & $\mathbf{E}$ & $\begin{array}{l}\text { Partial restricting: demolition and reconstruction works for some } \\
\text { components, including structural ones which imply the partial } \\
\text { transformation of the building: performance of a critical circulation, } \\
\text { modification of the bridging mark. }\end{array}$ \\
\hline & $\mathbf{F}$ & $\begin{array}{l}\text { Global restricting: demolition and reconstruction works for some } \\
\text { components, including structural ones which imply the complete } \\
\text { transformation of the building: repartitioning at the level of the } \\
\text { building, spaces fusion, extensions, modifications of the closings by } \\
\text { keeping value characteristics in relation to the assembly/reconstruction. }\end{array}$ \\
\hline & G & Demolition. \\
\hline & $\mathbf{H}$ & sas. \\
\hline
\end{tabular}

\section{Case study - application}

We choose an old street which connected before 1980 the Dambovita River with the south part of the city. Once, the fluency of the street was blocked, the initial owner was evacuated and the procedure to regaining the property are very confusing. The building stock was destroyed and occupied by homeless.

The state (vulnerability) value is 3.5 more than the reference value (2.50). The buildings must be strengthened as it results from intersection point in decision matrix. 


\subsection{Image of study area G. Georgescu Street}

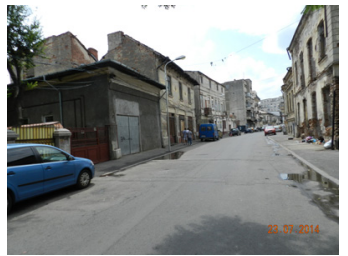

Figure 15: Image 1 [8].

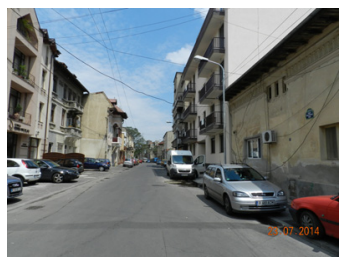

Figure 17: Image 1 [8].

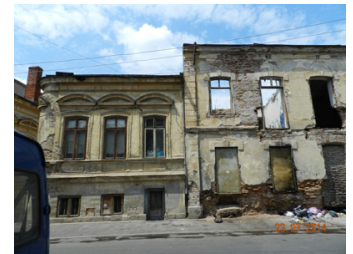

Figure 16: Image 1 [8].

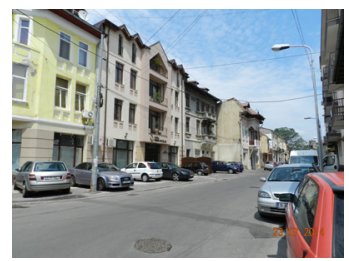

Figure 18: Image 1 [8].

\subsection{Analysis of study area}

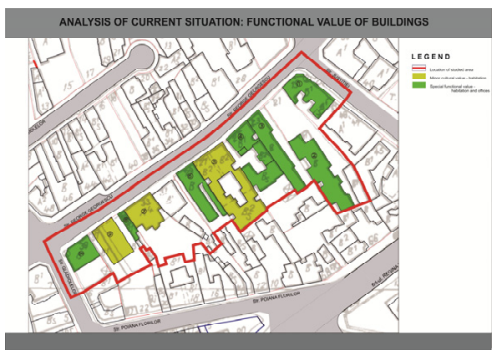

Figure 19: Cultural value [30].

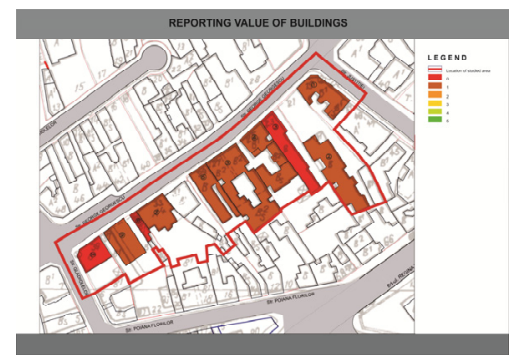

Figure 21: $\quad$ Reporting value [30].

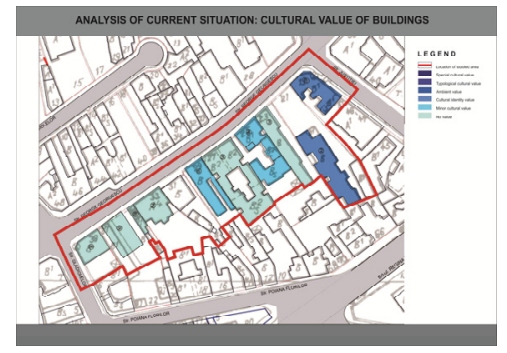

Figure 20: Functional value [30].

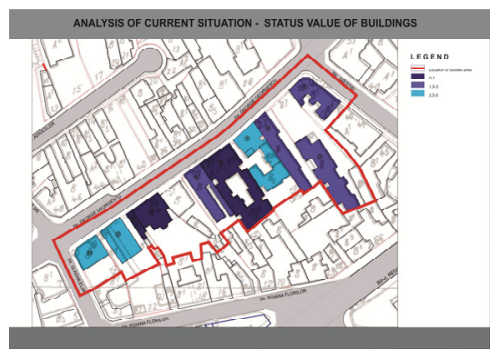

Figure 22: $\quad$ Status value [30]. 


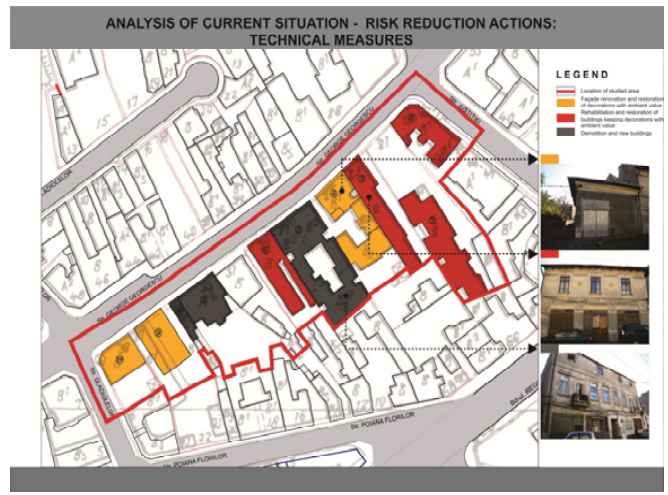

Figure 23: Intervention decision [30].

Table 5: Final decisions for building of area G. Georgescu Street.

\begin{tabular}{|c|c|c|c|c|c|c|}
\hline \multirow{2}{*}{$\begin{array}{c}\text { Reference } \\
\text { Value }\end{array}$} & \multicolumn{6}{|c|}{ State value (vulnerability) } \\
\cline { 2 - 7 } & 0 & 1 & 2 & 3 & 4 & 3.5 \\
\hline 5 & A & B & C & D & E/F & G/H \\
\hline 4 & A & B & C & D & E/F & G/H \\
\hline 3 & A & B & C & D & E & F \\
\hline 2.50 & A & B & E & F & G/H & G/H \\
\hline 2 & A & B & E & F & G/H & G/H \\
\hline 1 & A & B & E & F & G/H & G/H \\
\hline 0 & & & & &
\end{tabular}

\section{Conclusions}

The proposed type of multilevel investigation and decisions will be an instrument in architectural and urban projects of protected zone and can be implemented like a methodology for buildings fund affected by multi-hazard and especially by earthquake. This survey aims during its first stage at identifying the major structure underlying the building fund exposed to multiple hazards in a balanced relationship between cultural, functional affiliation value as an identity dimension as state value (vulnerability).

The final objectives are to relate to identifying the methodologies of setting out territory intervention decision-making. The field investigation start from preparing an analytical data sheet including general information and the specific evaluations in terms of cultural, functional, affiliation state vulnerability value are to be made by specialists relying on agreed criteria. Intervention policies are the results of holistic interpretations having in view that a patrimonial habitat is the most vulnerable but refers to community stability marks in the area. 


\section{Acknowledgements}

Funding for this research was provided by the Romania Ministry of National Education UEFISCDI Agency in the framework of the National Plan for Research, Development and Innovation, PNII, Partnership Program, Project "Urban blocks in Central Protected Area in Multiple Hazard Approach Assessment, Mapping and Strategies for Risk Mitigation. Case Study: Bucharest Destructured Zone by Razing Occurring in the Communist Period", under the Contract Number 53/2012, Project URBASRISK.

\section{References}

[1] "Ion Mincu" University of Architecture and Urbanism - Municipality of Bucharest site - General urban Plan of Bucharest, 2000.

[2] www.portmanteu.ro - Building area demolished at Nicolae Ceausescu order in the old city centre.

[3] Cartplus Catalogue Europe seismic map.

[4] Brundtland Report, 1998.

[5] Rowe, Stan J. "Ecocentrism: the Chord that Harmonises Humans and Earth" http://www.ecospherics.net/pages/RoweEcocentrism.html, 1994.

[6] Budeanu Constantin, Calinescu Emanoil. Elements of urban ecology. Edited by Editura Ştiinţifică şi Enciclopedica, 1982.

[7] Report no. P-2240-RO, World Bank, 1978.

[8] Code P100-1/2013, MDRAP, 2012.

[9] Personal archive photography, 2013.

[10] Aerial view of the studied area, retrieved from https://maps.google.ro/, founders of www.google.com Larry Page, Sergey Brin, 2013.

[11] Cavalcanti, M., "Urban reconstruction and autocratic regimes: Ceausescu's Bucharest in its historic context". Planning Perspectives, 12 (1997) 71-109. ISSN 0266-5433. Retrieved on April 6, 2012 from Taylor \& Francis Online, http://www.tandfonline.com/toc/rppe20/12/1, 1997 (2012).

[12] Norberg-Schulz, C., Existence, space and architecture - Studio Vista Books, London, 1971.

[13] Budeanu Constantin, Calinescu Emanoil. "Elements of human ecology". Edited by Editura Ştiinţifică şi Enciclopedica, p. 32, 1982.

[14] Pitulac Tudor - Community sociology - Iasi: European Institute, p.31, 2009.

[15] Tonnies Ferdinand - Community and Civil Society - Jose Harris (Editor), Cambridge University, (trad in engleza Jose Harris si Margaret Hollis), 2001.

[16] Gociman C.O., Dinu E. The definition of urban habitat as a safety tool against global risk, page 306 / Post Disaster reconstruction Meeting Stakeholder Interests, Firenze University Press 2007, Edited br David Alexander, Colin Henry Davidson, Andrew Fox, Cassidi Johnson and 
Gonzalo Lizzaralde, retrieved on April 6 from http://elsa.jrc.ec.europa.eu /publications/JRC41722.pdf, 2007.

[17] Heidegger M. "Building Dwelling Thinking in Poetry Language Thought - Harper - Perenial - New York (2001), pp. 147-148. 1975.

[18] Lynch, K. - The image of the City, Cambridge, Mass. Technology Press and Harvard Univ. Press, 1960.

[19] Gould Stephen Jay, "On mental maps" University Community of Mathematical Geographers Discussion Papers 9, 1966.

[20] Blessing, C.A. (1960) - Perception on planning, J of Amer. Institute of Planners, 16 February, pp. 2-4.

[21] Wolpert, J., Migration as an adjustment to environmental $\mathbf{J}$ of Social Issues, 22, pp. 92-102, 1966.

[22] Declaration of Amsterdam, 1975 Congress of the European Architectural Heritage, 21-25.10.1975 p1/9 retrieved on http://www.icomos.org/en/ charters-and-texts/179-articles-en-francais/ressources/charters-andstandards/169-the-declaration-of-amsterdam, 1975.

[23] Convention for the Protection of the Architectural Heritage of Europe. Introduction line 7. Granada, 3.X.1985. Retrieved on April 6, 2014 from http://conventions.coe.int/Treaty/en/Treaties/Html/121.htm, 2014 (1985).

[24] Romanian Academy archive.

[25] List of Romanian Monuments.

[26] Gociman C.O., Moscu C.I., Florescu T., Georgescu S.E. "Decision on Building Stock Survival and Conservation in a Multihazard Environment International Conference on Climate Change, Ecology and Conservation, ICCCEC 2014, Macau, China, 13-14 February 2014.

[27] Sandi, H; Pomonis, A.; Francis S.; Georgescu E.S.; Mohindra, R.; Borcia, I.S.: The development of a national system of earthquake evaluation. 30 years from the earthquake on 4 March 1977, Bucharest, Romania, 1-3 March 2007 Construction nr.1/2008.

[28] URBASRISK, Project "Urban blocks in Central Protected Area in Multiple Hazard Approach - Assessment, Mapping and Strategies for Risk Mitigation. Case Study: Bucharest Destructured Zone by Razing Occurring in the Communist Period", 2012-2015, UAUIM and UEFISCDI Agency, retrieved on April 62014 from http://www.uauim.ro/cercetare/ urbasrisk/en/ (2012).

[29] Gociman C., Timotei F., Varzaru A. project "Disaster risk reduction", URBASRISK workshop 2014.

[30] Ion Mincu University of Architecture and Urbanism - Municipality of Bucharest Site Urban Project plan of Protected Areas, 2001. 